\title{
Competitiveness and its determinants: \\ a systemic analysis for developing countries
}

\author{
Victor Medeiros, Lucas Gonçalves Godoi \\ and Evandro Camargos Teixeira
}

\begin{abstract}
This paper seeks to make a comparative and econometric analysis of competitiveness in developing countries, identifying its determinants and sources of variation. It uses the data envelopment analysis methodology to generate measures of competitiveness. The determinants of competitiveness are obtained through a Tobit model based on the systemic competitiveness approach. As average competitiveness is low, the main results show that resource allocation could be improved in many of the countries in the sample. In addition to business factors such as innovation and the sophistication of the business environment, structural aspects such as market size and quality of demand, along with systemic factors such as infrastructure, health, education, workforce training and the macroeconomic environment, are all important for enhancing the competitiveness of emerging countries.
\end{abstract}

\section{Keywords}

Economic growth, competitiveness, productivity, industrial efficiency, developing countries, comparative analysis, econometric models

JEL classification

C24, O20, 057

\section{Authors}

Victor Medeiros is a doctoral student in economics at the Faculty of Economic Sciences, in the Centre for Regional Development and Planning of the Federal University of Minas Gerais, Brazil. Email: victor-medeiros@cedeplar.ufmg.br.

Lucas Gonçalves Godoi holds a master's degree in economics from the Ribeirão Preto School of Economics, Administration and Accounting of the University of São Paulo, Brazil. E-mail: lucasgodoi@usp.br.

Evandro Camargos Teixeira is an assistant professor in the Department of Economics of the Federal University of Viçosa, Brazil. Email: evandro.teixeira@ufv.br. 


\section{Introduction}

According to Ferraz, Kupfer and Haguenauer (1996), competitiveness can be defined as a firm's capacity to create and implement competitive strategies and to sustainably maintain or increase its product share in the market. These capacities are associated with various factors, which may or may not be controlled by the firms, ranging from staff technical training and managerial-administrative processes, through to public policies, infrastructure supply and the specific features of demand and supply.

Competitiveness is important because it is positively related to long-term economic growth. A country can be considered competitive when it manages its resources and skills in such a way that, in addition to increasing the production of its firms, it improves its citizens' quality of life (IMD, 2012). According to a standard definition provided by the European Union (2001), competitiveness, at the regional and national levels, is the capacity of a region or country to achieve high and rising standards of living and high rates of employment on a sustainable basis.

Some authors have investigated the key determinants of competitiveness and how they relate to the process of economic growth and development in the different countries. According to the different theoretical approaches, the main determinants of competitiveness -and, consequently, economic growth - include: capital investments, the division of labour and trade, in classical theory; capital intensity, investment and government subsidy and tax policies, in the Keynesian approach; structural change, open trade and foreign direct investment (FDI), from the development economics standpoint; and the education level, expenditure on human capital, research and development (R\&D) and incentives for innovation, in the "new growth theory". 1

Endogenous growth theorists have also highlighted issues such as human capital (Lucas, 1988), innovations (Romer, 1990; Aghion and Howitt, 1992), infrastructure (Barro, 1990), institutions (Romer, 1986) and competition and trade openness (Grosmman and Helpman, 1991).

Ferraz, Kupfer and Haguenauer (1996) developed a dynamic process approach to competitiveness, in which a country's competitiveness is determined and constrained by a variety of business, structural and systemic factors. In this dynamic approach, competitive advantages stem from variables that are relevant for competitiveness at all levels of the system and from the interaction between them. It is thus concluded that competitiveness is systemic (Esser and others, 1996).

Empirical evidence has corroborated the aforementioned theoretical studies. Although the body of literature is not very extensive, the hypothesis of a positive relationship between competitiveness and economic growth has been demonstrated, as, for example, in the research by Kordalska and Olcyzk (2016). ${ }^{2}$

Using the data envelopment analysis (DEA) methodology, other studies have measured countries' levels of competitiveness and its determinants through a comparative analysis (Rocha, Rebelatto and Camioto, 2015; Ülengin and others, 2011; Charles and Zegarra, 2014). These authors treat competitiveness as an ex ante concept, such that a country would be considered competitive if it allocated its resources at least as efficiently as other countries. One of the main findings is that factors such as education, geography, income equality, good institutions and the provision of public goods can play an important role in enabling countries to use their resources efficiently and, thus, be more competitive.

This article aims to contribute to the specialized literature on competitiveness by providing additional evidence on its key determinants in developing countries, through a comparative and econometric analysis spanning 2011-2014, since no studies have considered these two aspects together. The choice of emerging countries is justified by the fact that they lag behind the rest of the

\footnotetext{
1 For further details, see Kordalska and Olcyzk (2016).

2 In this case a panel data model was used.
} 
world in terms of competitiveness (as reported, for example, in the Global Competitiveness Index (GCI)), since improving factors that increase a country's competitiveness could be important in fostering its sustained economic growth. ${ }^{3}$

To achieve the objectives of this study, the DEA methodology will be used to generate countryefficiency measures based on an aggregate production function. These measures will then be used as a proxy for a nation's comparative competitiveness. In addition, the Malmquist index will be used to obtain variations in total factor productivity (TFP) and its decomposition into change factors (technical changes and changes in technical efficiency). ${ }^{4}$ An econometric model will then be estimated to establish the determinants of competitiveness and thus provide additional evidence on policies that could be implemented to increase competitiveness and continue the process of economic growth in the sample countries. The determining factors will themselves be identified through principal components analysis, because of the high degree of multicollinearity that exists between the variables in question.

This article is divided into five sections, including this introduction. Section II outlines the theoretical framework, and section III describes the methods used in the study. Section IV sets out the results, and the fifth and final section summarizes the main conclusions.

\section{Growth, competitiveness and their determinants: a systemic approach}

The literature defines competitiveness through various concepts and indicators. As a performance concept, competitiveness is related to the country's industrial export earnings. According to this ex post approach, firms are competitive when they succeed in growing their share of the international market for certain products (Haguenauer, 1989). In addition to production conditions, the performance concept of competitiveness identifies factors that stimulate or discourage exports in specific products and countries, such as exchange-rate and trade policies, the efficiency of marketing channels and financing systems, international agreements, and business strategies.

Other authors see export performance as an immediate consequence of competitiveness, rather than the reverse. This concept of competitiveness is potential, ex ante, and traditionally linked to production conditions. In terms of efficiency, competitiveness is defined as a country's capacity to produce a given good in conditions that are at least as good as in other economies (Haguenauer, 1989).

Under the efficiency approach, the country that is able to generate the greatest output is considered competitive, relative to other countries, given the resources available to it. Accordingly, a simple aggregate production function can be considered, described by:

$$
Y=A K^{\alpha} L^{1-\alpha}
$$

where $Y$ represents output, $K$ the level of capital, and $L$ the number of workers, while $\alpha$ is a positive parameter, between 0 and 1, representing the return on capital. A country would be considered efficient if it uses its capital and labour inputs to generate the greatest possible output, while holding technology constant. In this case, the country would be at the production technology frontier, so its factors of production would not be wasted, and its population would have the highest possible level of income.

3 The choice is also justified by other shared characteristics of the countries analysed, such as lower levels of per capita income than developed countries, an export model consisting mainly of products of lower technological content, and worse human development indicators. In terms of methodology, the fact that these countries share similar characteristics also makes the analysis based on DEA and its comparative approach more realistic.

4 Authors who have used this methodology to evaluate TFP for developing countries include Marinho and Bittencourt (2007) and Araujo, Feitosa and Da Silva (2014). 
This article conceptualizes competitiveness in terms of efficiency, since its objective is to determine the relative efficiency of developing countries. However, since this measure alone is insufficient to encompass the breadth of the term "competitiveness", its determining factors also need to be analysed, following the approach of Ferraz, Kupfer and Haguenauer (1996). These authors seek a dynamic approach that provides a benchmark for competitiveness by analysing the competitive process. In this context, competitiveness is defined as a firm's capacity to create and implement competitive strategies and sustainably maintain or increase its market share.

The performance and productive efficiency of firms are likely to be related to the capacity accumulated over time, which would influence their competitive strategies. These, in turn, would vary according to the economic environment and the competitive process in which the firm operates. Competitiveness would thus be understood as a measure that encompasses more than one given firm, but that is directly related to the pattern of competition in a specific market.

Patterns of competition would be influenced by the composition of the firm's competitive environment, in other words by the structural and behavioural components of a given economic sector or system. These patterns stem from the interdependence that exists between competitive firms or sectors through technological complementarities, constraints and incentives to the flow of goods, in addition to the availability of infrastructure, laws, planning systems and industrial policies, among other factors. Competitiveness in this sense would be the capacity of companies to adapt their strategies to the pattern of competition prevailing in their sector.

The analysis of competitiveness thus needs to consider the diversity of factors that are capable of generating competitive advantages - such as sales efforts, training for production, access to sources of raw materials and to suppliers of parts and components, in addition to those directly linked to innovation and the dissemination of new techniques (Ferraz, Kupfer and Haguenauer, 1996). Thus, a dynamic approach to competitive performance is created by incorporating its business, structural and systemic determinants. In other words, competitiveness is essentially systemic (Esser and others, 1996).

"Business factors" are those over which the enterprise has substantial control. These include the cumulative knowledge generated by the firm and its strategies and, more specifically, management effectiveness, training and performance, technological training in processes and products, organizational methods and human resources, among others.

"Structural factors" are those over which the enterprise does not have full control; that is, firms are constrained by the competition process itself and its specifics. Apart from the characteristics of demand and supply, these include the influence of non-market institutions that define the regime of incentives and regulation, geographical distribution, the degree of technological sophistication, growth rates, marketing systems and opportunities for access to international products, among others (Ferraz, Kupfer and Haguenauer, 1996).

"Systemic factors" are those over which the firm has little or no control. These generate conditions that are external to the firm but serve as parameters of the decision-making process. They include the following types of factors: infrastructural (availability, quality and cost of energy, transport, telecommunications, basic inputs and technological services; macroeconomic (exchange rate, tax burden, the growth rate of gross domestic product (GDP), credit supply and interest rates, and wage policy); political-institutional (tax policy, tariff policy, fiscal support for technological risk-taking, government purchasing power); social (labour training system, education policies and training of human resources, labour and social security); legal and regulatory (policies for industrial property protection, conservation of the environment, defence of competition and consumer protection); and international (trends in world trade, international capital flows, risk investments and technology, relations with multilateral organizations).

Diagram 1 illustrates the scope of the term competitiveness with the firm as the central element, which in turn is affected by the economic structure and system. 
Diagram 1

Determinants of competitiveness

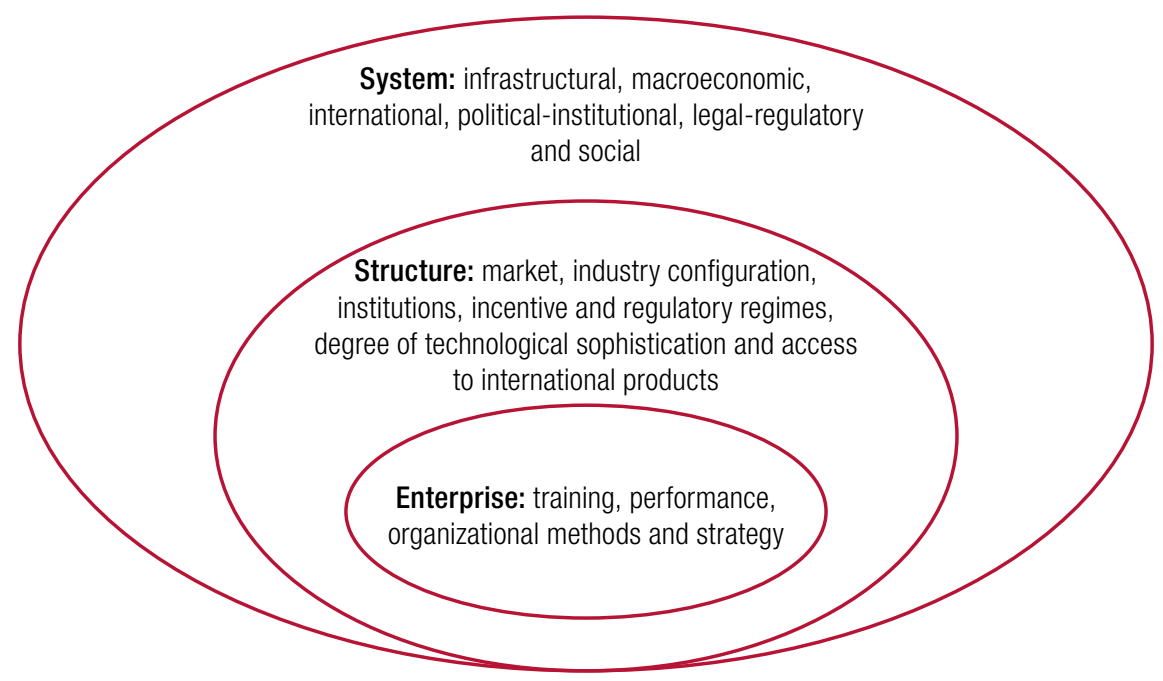

Source: Prepared by the authors, on the basis of J. Ferraz, D. Kupfer and L. Haguenauer, Made in Brazil: desafios competitivos para a indústria, Rio de Janeiro, Campus, 1996.

In the context illustrated in diagram 1, it would be important to define not only measures of relative efficiency (or competitiveness) between countries, but also the determinants of their competitiveness, to be better able to design public policies to improve the competitive environment of firms and expand their consequent benefits for the population in terms of economic growth and development.

\section{Methodology}

Two methodologies will be applied to achieve the objectives proposed in this study. In the first, data envelopment analysis (DEA), will be used to measure the efficiency of factors of production in developing countries. As this involves panel data, a further aim will be to assess the trend of TFP through the Malmquist index. Next, a Tobit model will be used with panel data to identify the key determinants of competitiveness in the sample countries, with the efficiency measures provided by the DEA methodology as dependent variable. However, as the explanatory variables of the Tobit model display a high degree of multicollinearity, principal components analysis will be used to construct indices to capture the importance of the different variables.

\section{Efficiency differences between developing countries and their determinants: methodology}

\section{(a) Efficiency measures}

The DEA methodology generates relative measures of efficiency between units of analysis, in other words within a given sample group. These measures are obtained through linear programming, and each production unit is treated as a decision-making unit (DMU). 
In DEA, it is assumed that there are $m$ outputs and $k$ inputs for each of the $n$ DMUs. From these data, input matrices (dimension $k \times n)$ and output matrices $(m \times n)$ are constructed to represent the various decision-making units. The methodology thus aims to measure efficiency as the ratio between outputs and inputs, as follows:

$$
\text { Efficiency of } D M U_{i}=\frac{u^{\prime} y_{i}}{v^{\prime} x_{i}}=\frac{u_{1} y_{1 i}+u_{2} y_{2 i}+\ldots+u_{m} y_{m i}}{v_{1} x_{1 i}+v_{2} x_{2 i}+\ldots+v_{k} x_{k i}}
$$

where $u$ is an ( $m \times 1)$ vector of output weights and $v$ is a $(k \times l)$ vector of input weights. Since the values of the output and input variables may differ substantially across DMUs, the weights attributed for the scope of the efficiency measures will also vary. This makes it necessary to formulate a problem that generates appropriate sets of weights for each DMU relative to the others.

As Ferreira and Gomes (2009) explain, the problem must be formulated to take account of the values of $u$ and $v$, in order to maximize the efficiency measure for each DMU, subject to the constraint that the measures of all DMUs are no greater than one. Assuming variable returns to scale, ${ }^{5}$ the following maximization problem is obtained:

$$
\operatorname{Max}_{\theta, \lambda} \theta
$$

subject to

$$
\begin{aligned}
& -\theta y_{i}+Y \lambda \geq 0, \\
& x_{i}-X \lambda \geq 0 \\
& N_{1}^{\prime} \lambda=1 \\
& \lambda \geq 0
\end{aligned}
$$

$N_{1}^{\prime} \lambda=1$ is the convexity constraint and $N_{1}$ is an $\left(\begin{array}{lll}n & 1\end{array}\right)$ unit matrix; $1 / \theta$ is a scalar, whose value will be the efficiency measure of the $i$-th DMU. If $\theta$ is equal to 1 , the DMU is considered efficient; if $\theta$ is less than 1 the DMU is inefficient. The parameter $\lambda$ is an $(n x 1)$ vector for which the values are calculated to obtain the optimum solution.

For an efficient DMU, all values of $\lambda$ will be zero; and for an inefficient one, the values of $\lambda$ will be the weights used in the linear combination of other efficient DMUs, which influence the inefficient DMU's projection on the calculated frontier. This means that, for every inefficient unit, there is at least one efficient unit, for which the calculated weights will provide the virtual DMU of the inefficient unit, through linear combination.

Accordingly, the DEA methodology seeks to generate country efficiency measures that represent each country's competitiveness relative to the others, since these measures will demonstrate the highest possible level of output, given the allocation of inputs (output orientation). The input variables $X 1$ (number of persons employed) and $X 2$ (capital stock, valued at purchasing power parity) will be used, together with the output variable $Y 1$ (GDP at purchasing power parity).

\section{(b) Malmquist index and total factor productivity}

The Malmquist index is used to estimate the variation in TFP. As described in Coelli, Rao and Battese (1998), the Malmquist TFP index measures the variation in TFP between two periods, so it is a time-bound measure of productivity.

\footnotetext{
5 For further details, see Charnes and others (1994) and Cooper, Seiford and Tone (2000).
} 
The pioneering study by Malmquist (1953) finds that there are two effects that can influence factor productivity over time: (i) the recovery or catch-up effect, which determines the capacity of a $\mathrm{DMU}$ to approach the efficiency frontier, given an available technology; and (ii) the displacement effect, which captures the displacement of the efficiency frontier through time, in other words a change in the technology that alters productivity. The Malmquist index can be used to calculate the effects described, as follows:

$$
\text { Malmquist index }=\text { catch-up effect } x \text { displacement effect }
$$

In addition to obtaining efficiency measures for developing countries, this study seeks to identify any technological or technical efficiency developments in 2011-2014 and, consequently, track the behaviour of TFP in that period. The Malmquist index complements the efficiency analysis by more precisely identifying the sources of variation in the efficiency of developing countries. In this case, the application of the model includes the year 2010, in order to obtain productivity variations from 2011 onwards.

\section{Econometric analysis}

\section{(a) Principal components analysis}

Given the high degree of multicollinearity that exists between the explanatory variables used in the econometric approach, many of them contain the same information. To overcome this problem, it was decided to use principal components analysis, which consists of transforming one set of original variables into another set of variables of the same dimension, called principal components.

The principal components are a linear combination of all the original variables and are therefore mutually independent. They are estimated sequentially, such that each one contains as much as possible of the information present in the original data. Thus, principal components analysis is a means of reducing the dimensions of the data with the least possible loss of information.

According to Zivot and Wang (2003), denoting the covariance matrix of the variables by $\hat{\Omega}$ and the matrix of the original variables after normalization by $Z$, the first principle component is given by $x_{1}^{*} Z$, in which $x_{1}^{*}$ is the solution to:

$$
\max _{x_{1}} x_{1}^{\prime} \hat{\Omega} x_{1} \text { s.t. } x_{1}^{\prime} x_{1}=1
$$

Thus, the solution $x_{1}^{*}$ is the value associated with the highest eigenvalue of $\hat{\Omega}$. The second component is $x_{2}^{*} Z$; and $x_{2}^{*}$ is the vector that solves the following expression:

$$
\max _{x_{2}} x_{2}^{\prime} \hat{\Omega} x_{2} \text { s.t. } x_{2}^{\prime} x_{2}=1 \text { and } x_{1}^{* \prime} x_{2}=0
$$

According to this solution, the $K$ principal components are calculated for $K$ original variables. In this way, the dimension of the dependent variables on the censored Tobit model will be reduced, by maintaining the components that account for $80 \%$ of the variance of the original variables in the problem.

Lastly, the elements of $x_{k}^{*}$ are recovered to define the importance of each of the "original" variables in forming the components and, consequently, each variable's impact on competitiveness. This mechanism will be implemented through a simple ordinary least squares (OLS) estimation of $x_{k}^{*}$ on $Z$. 


\section{(b) Regression model with censored data and resampling}

A Tobit model will be estimated to evaluate the determinants of competitiveness in developing countries. This model was chosen because the efficiency measures calculated through the DEA consist of a censored sample, since they are restricted to the interval $[0,1]$. In this case, when estimating through OLS, the parameters would be inconsistent and statistical inference on them would be infeasible (Wooldridge, 2011). ${ }^{6}$

Censoring may entail the loss or lack of data, and the sample may display censoring at the lower limit (on the left) or at the upper limit (on the right). With $Y$ as the dependent variable, I as a constant that represents the minimum value assumed by $Y$, and $S$ as its maximum value, then $Y$ will be observed only in the interval $[I, S]$, so the observations are considered censored at the lower $(I)$ and upper $(S)$ points.

Using the notations defined in the previous paragraph, together $Z^{\prime}$ the vector of explanatory variables, $\beta$ the vector of parameters to be estimated, $Y^{*}$ the estimated vector of $Y$, and $\varepsilon$ the random error term, the Tobit model can be described as follows:

$$
\begin{aligned}
& Y^{*}=Z^{\prime} \beta+\varepsilon_{i} \\
& Y=I, \text { if } Y^{*} \leq 1 \\
& Y=Y^{*}, \text { if } I<Y^{*}<S \\
& Y=S, \text { if } Y^{*} \geq S
\end{aligned}
$$

The model is estimated using the two-stage maximum likelihood method: the first stage uses a Probit model for the treatment of censored observations, and the second specifies a linear model for uncensored observations. The estimated coefficients can be interpreted as the effect of the regressors on the variable $Y^{*}$.

The Tobit model will use panel data, which makes it possible to examine the fixed or random effects of a given country or time periods on the efficiency measures (Park, 2005). However, according to Cameron and Trivedi (2005) and Da Silva and others (2015), there are a number of problems that make it difficult to use the Tobit model with fixed effects, such as the inconsistency of estimators for short panels, as is the case in this study, and in cases where individual effects are not uniform. As a solution, the authors propose using the random effects model.

In the random effects model to be used in this study, it is assumed that the random effect is identical for all periods and not correlated with the other regressors, that the angular coefficients are the same for all years and groups, and that the stochastic component of the model is not correlated between time periods (Greene, 2007).

Nonetheless, the Tobit estimator will only be consistent in the presence of homoscedastic and normally distributed errors (Gujarati and Porter, 2011). Otherwise, in the case of heteroscedasticity or non-normal errors, it would be better to use the bootstrap method, which estimates a given sample repeatedly to obtain the sample distributions of the parameters of interest and thus obtain robust estimates.

\footnotetext{
6 The inconsistency of the parameters stems from violation of the following assumptions of the classical linear regression model: the error term would not be independent and identically distributed and would not have a zero mean.
} 


\section{Source and treatment of the data}

The variables $X 1, X 2$ and $Y 1$, used in the DEA methodology, will be obtained from the Penn World Table 9.0 database. ${ }^{7}$ The countries considered in the sample correspond to the International Monetary Fund (IMF) ${ }^{8}$ classification of developing countries. After excluding countries for which no information was available, the sample used for application of the DEA model consisted of 82 countries.

The efficiency measure generated in the DEA will be used as a proxy for national competitiveness in the estimation of the Tobit model. The vector of explanatory variables in the econometric analysis will describe the determinants of competitiveness, according to the analysis reported by Ferraz, Kupfer and Haguenauer (1996), subdivided into business, structural and systemic factors. The synthesis of the variables used in the study and the respective sources are described in tables A1.1, A1.2, A1.3, A1.4 and A1.5 of Annex A1. Further details can be found in World Economic Forum (2014).

The variables Busin and Inov capture business factors related to the environment that mediates between firms and their capacity to adopt competitive strategies, and the capacity of firms to innovate and implement innovative practices, respectively. In this way they ultimately address the capacity of firms in a given country to implement competitive strategies.

With respect to structural factors, the variables Inst, Demand, Financ, Techn and Msize encompass, respectively, the role played in national competitiveness by institutional quality, demand conditions, the level of development of the financial market and its institutions, the availability of advanced technology and the size of the market.

Lastly, the variables Infra, Macro, Social, Train, Labour and Compet capture aspects related, respectively, to the supply and quality of infrastructure, the macroeconomic environment, primary education and health, labour force training and higher education, labour market efficiency, financial market quality and efficiency in the market for goods and services. These are also related to systemic factors.

In both the application of DEA and the econometric analysis, the variables were chosen in accordance with the specialized literature. Authors using similar variables include Ülengin and others (2011), De Paula and Da Silva (2015), Rocha, Rebelatto and Camioto (2015), Charles and Zegarra (2014) and Lábaj, Luptáčik and Nežinský (2013).

\section{Results and discussion}

\section{Data envelopment analysis and Malmquist index}

Application of the DEA model made it possible to observe the behaviour of developing countries in 2011-2014, considering an aggregate production function with capital and labour as inputs and GDP as output.

Table 1 reports the averages of efficiency, TFP variation and its respective decomposition into technical efficiency variation ( $\triangle$ Efficiency), or catch-up effect, and technological variation ( $\triangle$ Technology), or displacement effect. The maximum efficiency measure (equal to 1) shows that the country is at the technology frontier; in other words, it allocates its resources without waste, given the most advanced technology used. The first result reported in table 1 shows that many developing countries could allocate their resources more efficiently and, as a result, become more competitive.

\footnotetext{
7 Available [online] at https://www.rug.nl/ggdc/productivity/pwt/earlier-releases.

8 See [online] http://www.imf.org/external/pubs/ft/weo/2014/01/pdf/text.pdf.
} 
Table 1

Average measures of efficiency, catch-up effect, displacement effect and variation in total factor productivity (TFP): total sample, annual and average data for 2011-2014

\begin{tabular}{ccccc}
\hline Year/Measurement & Efficiency & $\Delta$ Efficiency & $\Delta$ Technology & TFP \\
\hline 2011 & 0.571 & 0.858 & 1.193 & 1.023 \\
\hline 2012 & 0.558 & 0.968 & 1.039 & 1.006 \\
\hline 2013 & 0.578 & 1.068 & 0.918 & 0.980 \\
\hline 2014 & 0.597 & 1.081 & 0.903 & 0.977 \\
\hline Average & 0.572 & 0.996 & 1.013 & 0.999 \\
\hline
\end{tabular}

Source: Prepared by the authors.

The variation in technical efficiency was negative in 2011 and 2012, a trend that is reversed in the ensuing years, with the variation becoming positive in 2013 and 2014. The opposite occurs with technological change, as the measure increases in 2011 and 2012 before dropping back in 2013 and 2014.

Overall, the cumulative TFP index shows that, on average, there was a slight decline (0.99) in productivity in developing countries. Following Young (1994), this would suggest that any economic growth in the countries analysed would be explained by an increase in the use of capital and labour inputs rather than by technological improvements. This result corroborates the study performed by Marinho and Bittencourt (2007), which explains the poor trend of TFP in developing countries, and specifically those in Latin America, owing to the lack of emphasis in those countries on policies promoting the systematic incorporation of technological innovations, the recognition of constraints on the formation of domestic savings, the high degree of infant industry protection and the inward-looking nature of the development process.

This moderate decline in TFP is mainly explained by negative variations in technical efficiency. This result seems to indicate that, on average, there was no convergence process in 2011-2014 between the countries analysed; in other words, the countries that were trailing in terms of productive efficiency failed to catch up with the more efficient countries.

The regional analysis (see table 2) shows that there were substantial differences between the regions analysed in 2011-2014. The average efficiency level, at 57.6\%, shows that many countries could improve their resource allocation. Asian and European countries had, on average, the best results, with average efficiencies of $68.5 \%$ and $65.7 \%$, respectively. In contrast, the African and Latin American countries had the worst indicators (averaging around $46.4 \%$ and $49.9 \%$, respectively).

Table 2

Average measures of efficiency, catch-up effect, displacement effect and variation in total factor productivity (TFP), by region, averages for 2011-2014

\begin{tabular}{lcccc}
\hline Sample & Efficiency & $\Delta$ Efficiency & $\Delta$ Technology & TFP \\
\hline Total & 0.576 & 0.989 & 1.007 & 0.996 \\
\hline Europe & 0.657 & 1.006 & 1.016 & 1.010 \\
\hline Latin America and the Caribbean & 0.499 & 0.986 & 1.017 & 0.991 \\
\hline Asia & 0.685 & 0.996 & 1.014 & 1.001 \\
\hline Africa & 0.464 & 1.001 & 1.008 & 0.999 \\
\hline
\end{tabular}

Source: Prepared by the authors.

In the case of TFP, only European countries recorded an average improvement in the period under review, while TFP in Asian and African countries remained practically constant. In contrast, the average for Latin American countries worsened, indicating a lag relative to the other countries in the sample during the period under analysis. 
The weak performance of African and Latin American countries in terms of efficiency and its variation can be explained partly by indicators of business, structural and systemic factors that are worse than in European and Asian countries. In the case of business factors (market sophistication and degree of innovation), figure 1 shows that the African countries had the lowest values for the Busin and Inov indicators. The Latin American countries also recorded the worst innovation indicator (Inov), identical to that of the African countries.

Figure 1

Business factors: average of values for 2011-2014

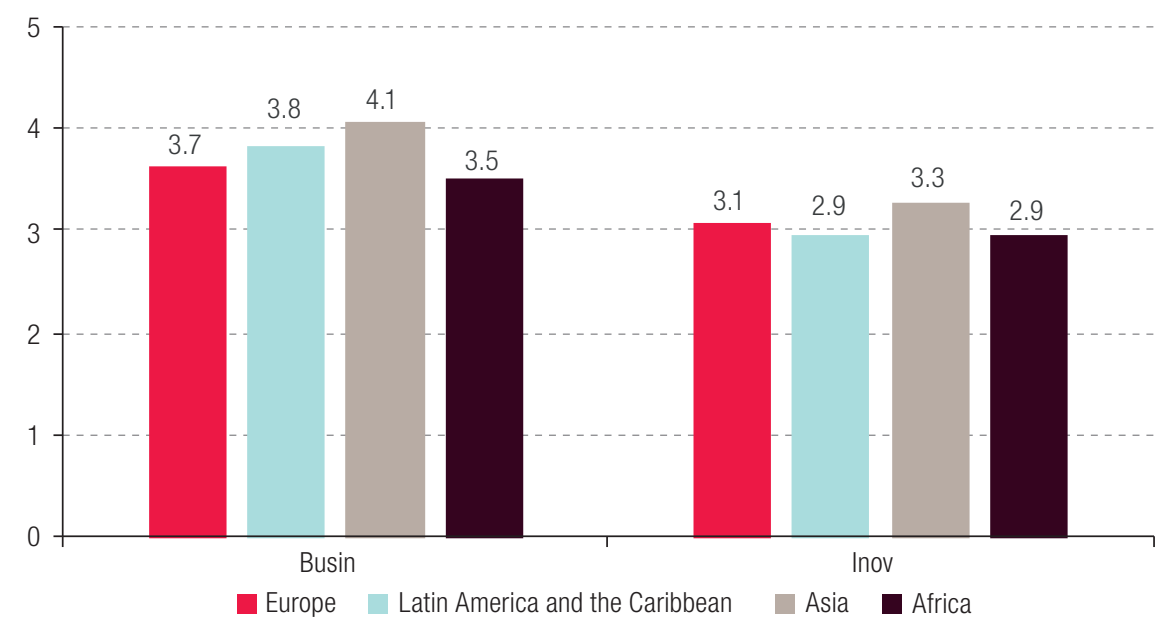

Source: Prepared by the authors, on the basis of World Economic Forum, "The Global Competitiveness Index", 2014.

In the case of structural factors, figure 2 shows that Asian countries again have the best indicators, whereas African and Latin American countries have the worst in terms of the quality of institutions, demand conditions, the quality of the financial system, availability of advanced technology and market size. The results are similar for systemic factors (see figure 3), which show that the countries that achieved the best efficiency averages in the DEA approach are generally the same as those with the best indicators of infrastructure, macroeconomic environment, basic education and health, technical training and higher education, skill level and labour legislation.

Figure 2

Structural factors: average of values for 2011-2014

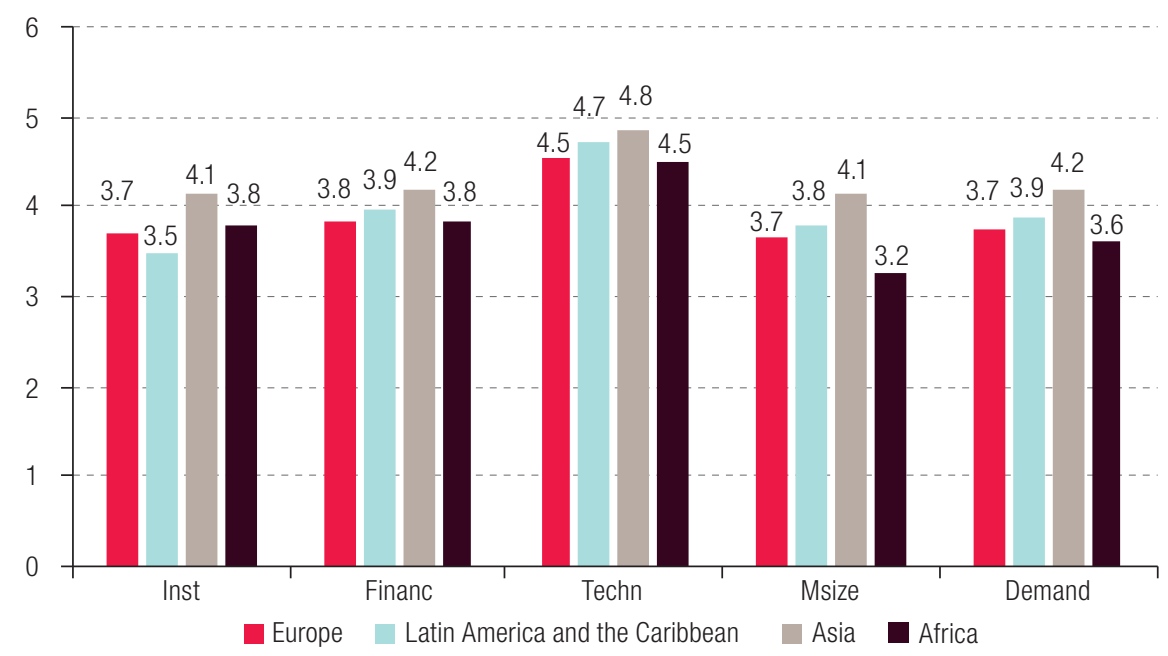

Source: Prepared by the authors, on the basis of World Economic Forum, "The Global Competitiveness Index", 2014. 
Figure 3

Systemic factors: average of values for 2011-2014

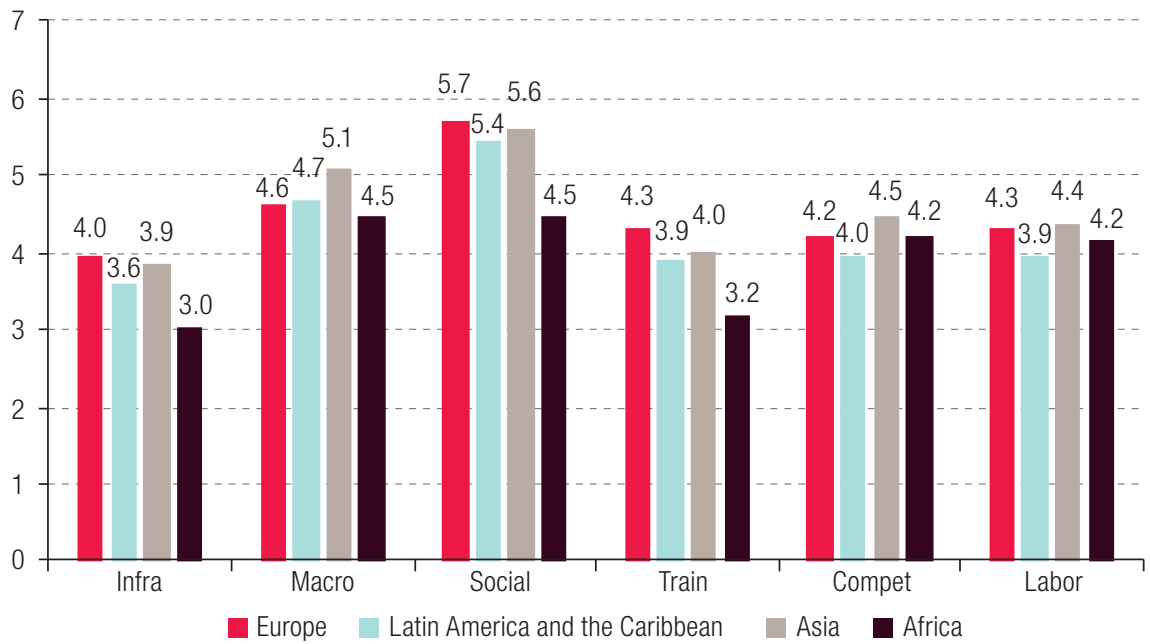

Source: Prepared by the authors, on the basis of World Economic Forum, "The Global Competitiveness Index", 2014.

Lastly, the best-performing countries in terms of technical efficiency were, Azerbaijan, Brunei Darussalam, China, Kuwait, Montenegro, Qatar, the Russian Federation and Saudi Arabia, which had efficiency measures equal to 1 in all years analysed. In these countries all of the average business, structural and systemic indicators are above average for the total sample, as shown in table 3.

Table 3

Average of business, structural and systemic indicators: total sample and countries with best efficiency scores, 2011-2014

\begin{tabular}{|c|c|c|c|c|c|c|c|c|}
\hline \multicolumn{3}{|c|}{ Business factors } & \multicolumn{3}{|c|}{ Structural factors } & \multicolumn{3}{|c|}{ Systemic factors } \\
\hline Indicator & Total & Best & Indicator & Total & Best & Indicator & Total & Best \\
\hline Busin & 3.79 & 4.18 & Inst & 3.77 & 4.49 & Infra & 3.60 & 4.49 \\
\hline Inov & 3.06 & 3.56 & Financ & 3.96 & 4.28 & Macro & 4.74 & 5.98 \\
\hline & & & Techn & 4.65 & 4.86 & Social & 5.30 & 5.87 \\
\hline & & & Msize & 3.72 & 4.16 & Train & 3.84 & 4.41 \\
\hline & & & Demand & 3.87 & 4.28 & Compet & 4.23 & 4.48 \\
\hline & & & & & & Labour & 4.20 & 4.65 \\
\hline
\end{tabular}

Source: Prepared by the authors, on the basis of World Economic Forum, "The Global Competitiveness Index", 2014.

As with the analyses conducted by Ferraz, Kupfer and Haguenauer (1996), IDM (2012) and the World Economic Forum (2014), the results described show that improved business, structural and systemic indicators can foster high levels of competitiveness and efficiency in developing countries.

In short, the results obtained through DEA indicate that the vast majority of the developing countries analysed have scope to improve the efficiency of their resource allocation, particularly the African and Latin American countries. Lastly, countries that achieved higher efficiency averages also display better business, structural and systemic indicators.

Nonetheless, some environmental factors or contextual variables can significantly influence the efficiency scores. Since competitiveness depends on structural, business and systemic factors, this diversity of factors needs to be assessed in relation to improved efficiency measurements. Thus, the following section uses a censored data model to estimate the impact of the different variables on the efficiency of developing countries. 


\section{Econometric analysis}

The first procedure in the statistical analysis entailed reducing the mass of data through principal components analysis, given the threshold that was imposed of only retaining in the analysis components that met the Kaiser criterion, in other words those that had eigenvalues greater than one. ${ }^{9}$ Accordingly, three of the 13 principal components were retained, as shown in table 4.

Table 4

Principal components analysis

\begin{tabular}{lccc}
\hline Component & Proportion & Cumulative & Eigenvalue \\
\hline Component 1 (PC1) & 0.5730 & 0.5730 & 7.4491 \\
\hline Component 2 (PC2) & 0.1270 & 0.7000 & 1.6512 \\
\hline Component 3 (PC3) & 0.0793 & 0.7793 & 1.0308 \\
\hline Component 4 (PC4) & 0.0630 & 0.8423 & 0.8192 \\
\hline No. of observations: 321 & & &
\end{tabular}

Source: Prepared by the authors.

Following the principal components analysis, a Tobit censored data model was estimated, with the efficiency measures generated by the DEA methodology as dependent variable and the components as explanatory variables. The censored data model was estimated using the bootstrap method, which is appropriate for solving or minimizing problems arising from the difficulty of determining an asymptotic error pattern, which tends to underestimate the true variance. Thus, the model was estimated by the bootstrap method, using Tobit estimations with random and pooled effects.

Table 5 reports the results of the estimations. There were no substantial differences (only in the magnitude of standard errors) between the pooled and random-effects estimates; and the results were identical in terms of the significance and sign of the variables.

Table 5

Determinants of competitiveness in developing countries: Tobit and ordinary least squares estimation, 2013

\begin{tabular}{lcc}
\hline Variable/Model & Random effect & Pooled \\
\hline PC1 & 0.0240 & 0.0240 \\
\cline { 2 - 3 } & $(0.0048)^{\star \star \star}$ & $(0.0042)^{\star \star \star}$ \\
\hline PC2 & 0.0349 & 0.0349 \\
\hline PC3 & $(0.0109)^{\star \star \star}$ & $(0.0111)^{\star \star \star}$ \\
\hline Constant & -0.0153 & -0.0153 \\
\hline Observations & $(0.0164)$ & $(0.0172)$ \\
\hline No. of left-censored observations & 0.6029 & 0.6029 \\
\hline No. of right-censored observations & $(0.0304)^{\star \star \star}$ & $(0.0321)^{\star \star \star}$ \\
\hline Wald chi-squared & 321 & 321 \\
\hline Prob>chi-squared & 0 & 0 \\
\hline
\end{tabular}

Source: Prepared by the authors.

Note: $\left.\quad{ }^{\star \star \star}\right)$ significant at 1\%; bootstrapping standard errors in parentheses.

Table 5 shows that the first two components both had positive and significant effects in terms of influencing the competitiveness of a given developing country. Accordingly, from this point onwards this study sought to recover the weights used to form the components, in order to extract information on the influence of the original variables.

9 For further information on component selection criteria, see Fávero and others (2009). 
To that end, the weights of each variable in the formation of the principal components were normalized, and then a model was estimated through OLS, with the components as dependent variables. Since the components are merely linear combinations of the original model variables, $R^{2}$ must in fact be 1 , so there is no standard error for the coefficients.

After applying the procedure described in the previous paragraph for the first component (PC1) - which generated a positive effect on the competitiveness of developing countries (see table 6) - all of the variables had a positive impact on competitiveness. The greatest weights are assigned to variables such as the business environment and the innovative capacity of the firms, and also to aspects such as infrastructure, demand conditions and quality, the competitive environment, health, basic education and the skill level of the workforce, institutions and the financial system, and access to advanced technologies.

Table 6

Weight of each main variable in the formation of the principal components

\begin{tabular}{|c|c|c|c|}
\hline Original variable/component & Type of factor & PC1 & PC2 \\
\hline Busin & \multirow[t]{2}{*}{ Business } & 0.3382 & 0.0449 \\
\hline Inov & & 0.3163 & 0.0338 \\
\hline Inst & \multirow[t]{5}{*}{ Structural } & 0.3079 & -0.2498 \\
\hline Financ & & 0.2991 & -0.1840 \\
\hline Techn & & 0.3133 & -0.1225 \\
\hline Demand & & 0.3256 & 0.0289 \\
\hline MSize & & 0.1207 & 0.5248 \\
\hline Infra & \multirow[t]{7}{*}{ Systemic } & 0.3148 & 0.1688 \\
\hline Macro & & 0.1986 & 0.1040 \\
\hline Compet & & 0.2838 & -0.3664 \\
\hline Social & & 0.2164 & 0.3991 \\
\hline Train & & 0.2797 & 0.3366 \\
\hline Labour & & 0.1950 & -0.4035 \\
\hline Observations & & 321 & 321 \\
\hline
\end{tabular}

Source: Prepared by the authors.

The second component also has a positive effect on competitiveness. The variables with the greatest weight in this component are: MSize, Social, Train, Compet and Labour. The impact of the first three on competitiveness is positive and that of the last two negative.

To make it easier to analyse table 6 , boxes shaded in dark grey indicate variables that weigh more heavily in determining the component, while those shaded in light grey indicate variables of minor importance in that regard. An analysis was made of the variables that obtained equivalent signs in relation to the competitiveness dependent variable and that were important in determining the components (that is, the variables Busin, Inov, Demand, MSize, Infra, Macro, Social and Train). The remainder of the variables (Inst, Financ, Techn, Compet and Labour) behave somewhat ambiguously, producing contrasting coefficients in components 1 and 2 (PC1 and PC2). Accordingly, a more in-depth analysis of their possible effects on efficiency will not be made.

The results obtained can be interpreted in three ways. Firstly, business factors are clearly important, as shown by the substantial weight of the variables Busin and Inov in PC1. Consequently, the competitiveness benefit derived from a sophisticated business environment - that is, an environment characterized by the large number and quality of local suppliers, breadth of the value chain, control of international distribution, sophistication of the production process, scope of marketing, among others - is proven; along with the innovative capacity of firms, in other words the quality of scientific research institutions, firms' R\&D spending, R\&D collaboration between universities and industries, government purchases of advanced technology products, the availability of scientists and engineers, patent applications and the protection of intellectual property, and others. These results corroborate the theoretical analysis performed by Romer (1990) and Aghion and Howitt (1992), for example. 
Secondly, with respect to structural factors, aspects such as market size (MSize) and, to a lesser extent, the quality of demand (Demand), which is observed in the degree of customer orientation and sophistication of the buyer, are important. This result corroborates the theoretical analysis conducted by Romer (1986) and Ferraz, Kupfer and Haguenauer (1996), among others.

In addition, the MSize variable had considerable weight in PC2, which indicates that economies of scale generated by large domestic and export markets are important factors enabling countries to become more competitive. This result supports the theoretical analyses of authors such as Grossman and Helpman (1991), which highlight the importance of trade openness for the growth process through greater competitiveness.

Thirdly, in the case of systemic factors, the relevant variables explaining the principal components were Infra, Social, Train and, to a lesser extent, Macro. Thus, fundamental factors include improved means of transport, quality of energy supply and telecommunications services, in addition to the provision of health, basic and higher education and workforce training. These results corroborate theoretical work done by Lucas (1988) and Barro (1990), for example, which emphasizes the contribution of infrastructure and human capital to a country's development. Similarly, aspects related to the government's budget balance, gross national savings, control of inflation and the public debt, as well as the country's credit rating, would also be important for developing country competitiveness.

In short, the econometric analysis highlighted the importance of human capital, infrastructure, economies of scale, macroeconomic stability and the innovative capacity of firms to achieve a more competitive environment in developing countries. These results corroborate the theoretical analysis of Ferraz, Kupfer and Haguenauer (1996) and concur with the arguments made by endogenous growth theorists and others. In relation to other empirical evidence, the results are similar, albeit indirectly, to those reported by Rocha, Rebelatto and Camioto (2015), De Paula and Da Silva (2015), and Charles and Zegarra (2014), when indicating that environmental factors are important for a country's competitiveness.

\section{Conclusions}

The aim of this paper has been to measure the level of competitiveness and its main determinants in developing countries, with an approach that analyses competitiveness as an ex ante concept; in other words, a country is considered competitive relative to other countries if it uses its capital and labour inputs in such a way as to generate the greatest possible output.

The DEA methodology was used to obtain the level of technical efficiency and scale of developing countries. The results showed that most of the countries in the sample could allocate their resources more efficiently, given their low average level of efficiency. It was also noted that the countries and regions that have achieved higher efficiency averages and have improved their total factor productivity according to the Malmquist index, have better business, structural and systemic indicators.

In the econometric analysis, the Tobit model identified the following factors as important in enabling developing countries to become more competitive: business factors such as innovative capacity and the sophistication of the business environment; structural aspects such as the size of domestic and external markets and the quality of demand; as well as systemic factors such as the supply and quality of infrastructure, health, basic and higher education, workforce training and the macroeconomic environment. These findings are based on principal components analysis, since the variables in question played an important role in determining the components.

The importance of the political and economic authorities in these countries is also noted, since the provision of economic infrastructure services, health-care and education, and the maintenance of a favourable macroeconomic environment can help countries achieve high levels of competitiveness and, 
consequently, reap benefits in terms of economic and human development. Accordingly, the business environment in which firms operate can be expected to be become more favourable, as a result of better-quality demand and increased market size. Ultimately, these factors can be expected to promote a business environment that is supportive of business decision-making, enabling firms to operate in a context that is conducive to innovation, thereby helping the country to become more competitive.

\section{Bibliography}

Aghion, P. and P. Howitt (1992), "A model of growth through creative destruction", Econometrica, vol. 60, No. 2, Hoboken, Wiley.

Araujo, J., D. Feitosa and A. da Silva (2014), "América Latina: productividad total de los factores y su descomposición”, CEPAL Review, No. 114 (LC/G.2629-P), Santiago, Economic Commission for Latin America and the Caribbean (ECLAC).

Barro, R. (1990), "Government spending in a simple model of economic growth", The Journal of Political Economy, vol. 98, No. 5, Chicago, The University of Chicago Press.

Cameron, A. and P. Trivedi (2005), Microeconometrics: Methods and Applications, Cambridge, Cambridge University Press.

Charles, V. and L. Zegarra (2014), "Measuring regional competitiveness through data envelopment analysis: a Peruvian case", Expert Systems with Applications, vol. 41, No. 11, Amsterdam, Elsevier.

Charnes, A. and others (eds.) (1994), Data Envelopment Analysis: Theory, Methodology, and Application, Dordrecht, Kluwer Academic Publishers.

Coelli, T., D. Rao and G. Battese (1998), An Introduction to Efficiency and Productivity Analysis, Dordrecht, Kluwer Academic Publishers.

Cooper, W., L. Seiford and K. Tone (2000), Data Envelopment Analysis: A Comprehensive Text with Models, Applications, References and DEA-Solver Software, Boston, Massachusetts, Kluwer Academic Publishers.

Da Silva, M. and others (2015), "Determinants of out-of-pocket health expenditure on children: an analysis of the 2004 Pelotas Birth Cohort", International Journal for Equity in Health, vol. 14, No. 53, London, BioMed Central.

De Paula, J. and O. da Silva (2015), "Fatores internos como determinantes da competitividade no comércio internacional: um enfoque gravitacional”, Revista Análise Econômica, vol. 33, No. 64, Porto Alegre, Federal University of Rio Grande do Sul.

Esser, K. and others (1996), "Competitividad sistémica: nuevo desafío para las empresas y la política", CEPAL Review, № 59 (LC/G.1931-P), Santiago, Economic Commission for Latin America and the Caribbean (ECLAC).

European Union (2001), Second Report on Economic and Social Cohesion, Brussels.

Fávero, L. and others (2009), Análise de dados: modelagem multivariada para tomada de decisões, Rio de Janeiro, Elsevier.

Feenstra, R., R. Inklaar and M. Timmer (2015), "The next generation of the Penn World Table", American Economic Review, vol. 105, No. 10, Nashville, Tennessee, American Economic Association.

Ferraz, J., D. Kupfer and L. Haguenauer (1996), Made in Brazil: desafios competitivos para a indústria, Rio de Janeiro, Campus.

Ferreira, C. and A. Gomes (2009), Introdução à análise envoltória de dados: teoria, modelos e aplicações, Viçosa, Editora UFV.

Godfrey, N. (2008), "Why is Competition Important for Growth and Poverty Reduction?", paper presented at the OECD Global Forum on International Investment VII, Organization for Economic Cooperation and Development (OECD), March.

Greene, W. (2007), LIMDEP version 9.0: econometric modeling guide, New York, Econometric Software.

Grossman, G. and E. Helpman (1991), "Quality ladders and product cycles", Quarterly Journal of Economics, vol. 106, No. 2, Oxford, Oxford University Press.

Gujarati, D. and D. Porter (2011), Econometria básica, São Paulo, McGraw Hill.

Haguenauer, L. (1989), "Competitividade: conceitos e medidas: uma resenha da bibliografia recente com ênfase no caso brasileiro", Texto para Discussão, No. 211, Rio de Janeiro, Federal University of Rio de Janeiro.

IMD (Institute for Management Development) (2012), World Competitiveness Yearbook 2012, Lausanne. 
Kordalska, A. and M. Olczyk (2016), "Global competitiveness and economic growth: a one-way or two-way relationship? Equilibrium", Equilibrium. Quarterly Journal of Economics and Economic Policy, vol. 11, No. 1, Warsaw, Institute of Economic Research.

Lábaj, M., M. Luptáčik and E. Nežinský (2013), "Data envelopment analysis for measuring of economic growth in terms of welfare beyond GDP", Department of Economic Policy Working Paper, No. 2, Bratislava, University of Economics in Bratislava.

Lucas, R. (1988), "On the mechanics of economic development", Journal of Monetary Economics, vol. 22, No. 1, Amsterdam, Elsevier.

Malmquist, S. (1953), "Index numbers and indifference surfaces", Trabajos de Estadística y de Investigación Operativa, vol. 4, No. 2, New York, Springer.

Marinho, E. and A. Bittencourt (2007), "Produtividade e crescimento econômico na América Latina: a abordagem da fronteira de produção estocástica", Estudos Econômicos, vol. 37, No. 1, São Paulo, University of São Paulo.

Moura, R. (2009), "Impacto do IDE no crescimento econômico do país receptor - teoria e evidência empírica", master's thesis, University of Porto [online] https://www.fep.up.pt/cursos/mestrados/megi/Tese_Rui\%20 Moura_final.pdf.

OECD (Organization for Economic Cooperation and Development) (2002), Foreign Direct Investment for Development: Maximising Benefits, Minimising Costs, Paris.

Park, H. (2005), "Linear regression models for panel data using SAS, Stata, LIMDEP, and SPSS" [online] http://rt.uits.iu.edu.

Ram, R. and K. Zhang (2002), "Foreign direct investment and economic growth: evidence form cross-country data for the 1990s", Economic Development and Cultural Change, vol. 51, No. 1, Chicago, The University of Chicago Press.

Rocha, R., D. Rebelatto and F. Camioto (2015), "Análise da eficiência de fatores nos países do BRICS a partir da aplicação da Análise por Envoltória de dados", RACEF - Revista de Administração, Contabilidade e Economia da Fundace, vol. 6, No. 1, São Paulo, Foundation for Research and Development of Administration, Accounting and Economics (FUNDACE).

Romer, P. (1990), "Endogenous technological change", The Journal of Political Economy, vol. 98, No. 5, Chicago, The University of Chicago Press.

(1986), "Increasing returns and long-run growth", The Journal of Political Economy, vol. 94, No. 5, Chicago, The University of Chicago Press.

Ülengin, F. and others (2011), "The competitiveness of nations and implications for human development", Socio-Economic Planning Sciences, vol. 45, No. 1, Amsterdam, Elsevier.

Vissak, T. and T. Roolaht (2005), "The negative impact of foreign direct investment on the Estonian economy", Problems of Economic Transition, vol. 48, No. 2, Abingdon, Taylor \& Francis.

Wooldridge, J. (2011), Introdução à econometria: uma abordagem moderna, São Paulo, Cengage Learning. World Economic Forum (2014), The Global Competitiveness Report 2013-2014, Geneva.

Young, A. (1994), "The tyranny of numbers: confronting the statistical realities of the east Asian growth experience", NBER Working Paper, No. 4680, Cambridge, Massachusetts, National Bureau of Economic Research (NBER).

Zhang, K. (2001), "How does foreign direct investment affect economic growth in China?", Economics of Transition and Institutional Change, vol. 9, No. 3, Hoboken, Wiley.

Zivot, E. and J. Wang (2003), Modeling Financial Time Series with S-Plus, New York, Springer. 


\section{Annex A1}

Table A1.1

Variables used in the data envelopment analysis (DEA) model and the Malmquist index

\begin{tabular}{ll}
\hline Variable in the source & Source \\
$\begin{array}{l}\text { Real GDP based on production at chained purchasing power parity (PPP) rates } \\
\text { (millions of dollars at 2011 prices) }\end{array}$ & $\begin{array}{l}\text { Penn World Table 9.0 (Feenstra, Inklaar } \\
\text { and Timmer (2015)) }\end{array}$ \\
\cline { 1 - 1 } Number of persons employed (millions) & \\
\hline Capital levels at current purchasing-power parity (millions of dollars at 2011 prices) &
\end{tabular}

Source: Prepared by the authors.

Table A1.2

Variables used in the principal components and Tobit analysis

\begin{tabular}{|c|c|c|c|}
\hline Index & Name & Variable & Variable in the source \\
\hline \multirow[t]{2}{*}{ Business } & Busin & Business Sophistication Quality Index (1-7) & Pillar 11: Business sophistication \\
\hline & Inov & Innovation quality index (1-7) & Pillar 12: Innovation \\
\hline \multirow[t]{5}{*}{ Structural } & Inst & Institutional quality index (1-7) & Pillar 1: Institutions \\
\hline & Financ & Financial market development quality index (1-7) & Pillar 8: Financial market development \\
\hline & Techn & Technology adoption (1-7) & A. Technology adoption \\
\hline & Msize & Market size quality index & Pillar 10: Market size \\
\hline & Demand & Demand conditions quality index (1-7) & B. Quality of demand conditions \\
\hline \multirow[t]{6}{*}{ Systemic } & Infra & Infrastructure quality index & Pillar 2: Infrastructure \\
\hline & Macro & Macroeconomic environment quality index (1-7) & Pillar 3: Macroeconomic environment \\
\hline & Social & Health and education quality index (1-7) & Pillar 4: Health and primary education \\
\hline & Train & Training and advanced schooling quality index (1-7) & Pillar 5: Higher education and training \\
\hline & Labour & Labour market efficiency quality index (1-7) & Pillar 7: Labour market efficiency \\
\hline & Compet & Market competition level and quality & A. Competition \\
\hline
\end{tabular}

Source: Prepared by the authors, on the basis of World Economic Forum, The Global Competitiveness Report 2013-2014, Geneva, 2014.

Table A1.3

Variables related to the variables used in the principal components analysis: business factors

\begin{tabular}{ll}
\hline Variable & Related variables \\
\hline $\begin{array}{l}\text { Busin: Sophistication of } \\
\text { the business environment }\end{array}$ & $\begin{array}{l}\text { Quantity of local suppliers, quality of local suppliers, state of cluster development, nature of competitive } \\
\text { advantage, breadth of value chain, control of international distribution, sophistication of the production } \\
\text { process, scope of marketing, willingness to delegate authority, reliance on professional management. }\end{array}$ \\
\hline $\begin{array}{l}\text { Inov. } \\
\text { Innovation capacity }\end{array}$ & $\begin{array}{l}\text { Innovation capacity, quality of scientific research institutions, business R\&D expenditure, R\&D collaboration } \\
\text { between universities and industries, government purchases of advanced technology products, availability } \\
\text { of scientists and engineers, patent applications, intellectual property protection. }\end{array}$ \\
\hline
\end{tabular}

Source: Prepared by the authors, on the basis of World Economic Forum, The Global Competitiveness Report 2013-2014, Geneva, 2014. 
Table A1.4

Variables related to the variables used in the principal components analysis: structural factors

\begin{tabular}{lll}
\hline & Public institutions & Private institutions \\
\hline Inst: Institutional aspects & $\begin{array}{l}\text { Property rights, intellectual property protection, embezzlement of } \\
\text { public funds, public trust in politicians, irregular payments and bribes, } \\
\text { judicial independence, favouritism in decisions by government officials, } \\
\text { squandering of public expenditure, oversight of the government, } \\
\text { efficiency of the legal framework in resolving disputes, efficiency of the } \\
\text { legal framework in terms of regulations, transparency in government } \\
\text { policymaking, commercial costs of terrorism, commercial costs of crime } \\
\text { and violence, organized crime, reliability of police services. }\end{array}$ & $\begin{array}{l}\text { Ethical behaviour of firms, sound } \\
\text { auding and reporting standards, } \\
\text { effectiveness of boards of directors, } \\
\text { interests, strong investor protection. }\end{array}$ \\
& Degree of customer orientation, buyer sophistication. & \\
\hline $\begin{array}{l}\text { Demand: Qualitative } \\
\text { aspects of demand }\end{array}$ & Financial market efficiency & Reliability and trust \\
\hline $\begin{array}{l}\text { Financ: Institutional } \\
\text { aspects of credit access }\end{array}$ & $\begin{array}{l}\text { Availability of financial services, financing through the local stock market, } \\
\text { easy access to loans, availability of venture capital. }\end{array}$ & $\begin{array}{l}\text { Bank soundness, stock exchange } \\
\text { regulation, legal rights index. }\end{array}$ \\
\hline $\begin{array}{l}\text { Techn: Availability } \\
\text { of technology }\end{array}$ & $\begin{array}{l}\text { Technology adoption } \\
\text { Availability of recent technologies, technology absorption at the enterprise } \\
\text { level, foreign direct investment (FDI) and technology transfer. }\end{array}$ & \\
\hline & Domestic market & External market \\
\hline Msize: Market size & Domestic market size index. & External market size index. \\
\hline
\end{tabular}

Source: Prepared by the authors, on the basis of World Economic Forum, The Global Competitiveness Report 2013-2014, Geneva, 2014.

Table A1.5

Variables related to the variables used in the principal components analysis: systemic factors

\begin{tabular}{|c|c|c|c|}
\hline & Transport & \multicolumn{2}{|l|}{ Electricity and telephony } \\
\hline $\begin{array}{l}\text { Infra: Infrastructure } \\
\text { aspects }\end{array}$ & $\begin{array}{l}\text { Quality of overall infrastructure, quality of } \\
\text { roads, quality of railways, quality of ports, } \\
\text { quality of air transport. }\end{array}$ & \multicolumn{2}{|c|}{ Quality of energy supply, mobile and fixed telephony subscriptions. } \\
\hline \multirow{2}{*}{$\begin{array}{l}\text { Macro: Macroeconomic } \\
\text { aspects }\end{array}$} & \multicolumn{3}{|c|}{ Government budget balance, gross national savings, inflation, public debt, country credit rating. } \\
\hline & Health & \multicolumn{2}{|l|}{ Primary education } \\
\hline \multirow[t]{2}{*}{ Social: Social aspects } & $\begin{array}{l}\text { Commercial impact of malaria, incidence of } \\
\text { malaria, commercial impact of tuberculosis, } \\
\text { incidence of tuberculosis, commercial impact } \\
\text { of AIDS, prevalence of AIDS, infant mortality, } \\
\text { life expectancy. }\end{array}$ & \multicolumn{2}{|c|}{ Quality of primary education, primary education enrolment rate. } \\
\hline & Education quantity & Education quality & On-the-job training \\
\hline \multirow[t]{2}{*}{ Train: Social aspects } & $\begin{array}{l}\text { Secondary enrolment ratio, tertiary } \\
\text { enrolment ratio. }\end{array}$ & $\begin{array}{l}\text { Quality of the education system, } \\
\text { quality of mathematics and } \\
\text { science teaching, quality } \\
\text { of school management. }\end{array}$ & $\begin{array}{l}\text { Local availability of specialized } \\
\text { research and training, extent } \\
\text { of staff training. }\end{array}$ \\
\hline & Domestic competition & \multicolumn{2}{|l|}{ External competition } \\
\hline \multirow[t]{2}{*}{$\begin{array}{l}\text { Compet: Legal and } \\
\text { regulatory aspects }\end{array}$} & $\begin{array}{l}\text { Intensity of local competition, extent of market } \\
\text { dominance, effectiveness of antitrust policy, } \\
\text { effect of taxation on investment incentives, } \\
\text { total tax rate, number of procedures needed } \\
\text { to set up a business, time needed to set up } \\
\text { a business, costs of agricultural policy. }\end{array}$ & \multicolumn{2}{|c|}{$\begin{array}{l}\text { Prevalence of trade barriers, trade tariffs, prevalence of foreign } \\
\text { ownership, trade impact of foreign direct investment (FDI) rules, } \\
\text { burden of customs procedures, imports as a percentage of GDP. }\end{array}$} \\
\hline & Flexibility & \multicolumn{2}{|l|}{ Efficient use of talent } \\
\hline Labour: Social aspects & \multicolumn{3}{|c|}{$\begin{array}{l}\text { Payments and productivity, reliance on professional management, country's ability to attract talent, country's ability } \\
\text { to retain talent, women's participation in the workforce. }\end{array}$} \\
\hline
\end{tabular}

Source: Prepared by the authors, on the basis of World Economic Forum, The Global Competitiveness Report 2013-2014, Geneva, 2014. 